\title{
The challenge of vector development in gene therapy
}

\section{S.U. Dani}

\section{Correspondence}

S.U. Dani

Laboratório de Gerontogenética

e Terapia Gênica

Departamento de Genética

FMRP, USP

14049-900 Ribeirão Preto, SP

Brasil

E-mail: sudani@rgm.fmrp.usp.br

Presented at the International Symposium "The Third Revolution on Vaccines: DNA Vaccines", Belo Horizonte, MG, Brasil,

November 3-7, 1997.

Publication supported by FAPESP.
Laboratório de Gerontogenética e Terapia Gênica, Departamento de Genética, Faculdade de Medicina de Ribeirão Preto, Universidade de São Paulo, Ribeirão Preto, SP, Brasil

\section{Abstract}

Gene therapy is the treatment of diseases based on the transfer of genetic information. Agents that carry or deliver DNA to target cells are called vectors (Latin vector: carrier, deliverer). Ideally, a vector should accommodate an unlimited amount of inserted DNA, lack the ability of autonomous replication of its own DNA, be easily manufactured, and be available in concentrated form. Secondly, it should have the ability to target specific cell types or to limit its gene expression to specific cell types, and to achieve sustained gene expression in the long term or in a controlled fashion. Finally, it should not be toxic or immunogenic. Such a vector does not exist and none of the DNA delivery systems so far available for in vivo gene transfer is perfect with respect to any of these points. Gene therapy and the means to promote it depend heavily on the development and improvement of new gene vector systems.

\section{Introduction}

Received October 15, 1998 Accepted November 9, 1998
Many different ways have been devised for introducing genes into mammalian cells and tissues. The simplest technique is the inoculation of naked DNA by means of microinjection, electroporation and biobalistics, the latter also known as the "gene gun" technique. More elaborate and more efficient ways include the use of self-assembling complexes of lipid-DNA (e.g., liposomes), protein-DNA, lipid-protein-DNA, and viral vectors. Viral vectors can be fragments of viral DNA containing the DNA to be transferred or the viral particle itself. The viral particle is rendered crippled or replication defective through the manipulation of the viral DNA, and the end product is a nonpathogenic viral vector carrying the genetic

\section{Key words}

- Gene therapy

- Gene transfer

- DNA delivery

- Viral vectors

- Diposomes

- Vector development information of therapeutic interest.

Five gene transfer systems most commonly used in gene therapy trials - retroviral vectors, adenoviral vectors, liposomes, biobalistics and adeno-associated viral vectors - accumulate a limited clinical experience of only a few hundred patients worldwide in the last eight years. Therefore, this mini-review is aimed at briefly discussing the main features of gene vector systems, rather than the clinical experience in the field of gene therapy.

\section{Chemical methods}

Chemical methods for gene transfer usually involve the generation of some kind of complex with purified DNA, and the application of this complex to cells in culture or, 
less frequently, in vivo (Table 1). A substantial portion of the cells endocytes the DNA and is capable of transporting at least part of it into the nucleus, where the DNA is transiently expressed for some days. However, only a tiny fraction (usually much less than one percent) of the cells keeps the DNA permanently, incorporating it into its chromosomes, and continuing to express the introduced genes. In these methods, the vector is a purified DNA molecule (e.g., a plasmid), usually engineered by cloning methods to

Table 1 - Chemical methods for introducing genes into mammalian cells.

\begin{tabular}{|c|c|c|}
\hline Method & Advantages & Disadvantages \\
\hline $\begin{array}{l}\text { DNA-calcium } \\
\text { phosphate }\end{array}$ & $\begin{array}{l}\text { - cell death during the } \\
\text { procedure is minimal } \\
\text { - important in the production } \\
\text { of recombinant viral vectors } \\
\text { - simple and cheap } \\
\text { - expression can be transient } \\
\text { or stable }\end{array}$ & $\begin{array}{l}\text { - good for ex vivo use only } \\
\text { - transfection efficiency is low } \\
\text { - low levels of transgene } \\
\text { expression } \\
\text { - transient expression }\end{array}$ \\
\hline $\begin{array}{l}\text { DNA-DEAE } \\
\text { dextran }\end{array}$ & $\begin{array}{l}\text { - more reproducible than the } \\
\text { above method }\end{array}$ & $\begin{array}{l}\text { - good for ex vivo use only } \\
\text { - transfection efficiency is } \\
\text { low and expression is transient } \\
\text { - it only works for some } \\
\text { cell types }\end{array}$ \\
\hline $\begin{array}{l}\text { DNA-lipid } \\
\text { (liposomes) }\end{array}$ & $\begin{array}{l}\text { - do not integrate into } \\
\text { host genome } \\
\text { - good for in vitro and in vivo } \\
\text { use } \\
\text { - carry large pieces of DNA } \\
\text { (as large as whole } \\
\text { chromosomes) } \\
\text { - can be targeted } \\
\text { - non-immunogenic } \\
\text { - preparations are free } \\
\text { from contaminants } \\
\text { (cf. viral vectors) } \\
\text { - high purity grade possible } \\
\text { - scale-up and standardization } \\
\text { possible }\end{array}$ & $\begin{array}{l}\text { - low transfection efficiency as } \\
\text { compared to viral systems } \\
\text { - usually transient expression of } \\
\text { the transgene } \\
\text { - slight cell toxicity } \\
\text { - inhibition by serum } \\
\text { components can occur }\end{array}$ \\
\hline DNA-protein & - same as above, though better & - same as above \\
\hline $\begin{array}{l}\text { DNA-lipid- } \\
\text { protein }\end{array}$ & $\begin{array}{l}\text { - targeting and better transfection } \\
\text { rates }\end{array}$ & \\
\hline $\begin{array}{l}\text { HACs } \\
\text { (human artificial } \\
\text { chromosomes) }\end{array}$ & $\begin{array}{l}\text { - do not integrate into host } \\
\text { chromosomes } \\
\text { - large inserts can be } \\
\text { accommodated } \\
\text { - better transcriptional control }\end{array}$ & - under development \\
\hline
\end{tabular}

contain, besides the gene of interest, regulatory sequences such as promoters and enhancers to facilitate the expression of the gene.

To improve efficiency and specificity, the DNA vector can be complexed to agents such as ligand proteins, to facilitate its entry into the target cells. An example is the use of conjugates of a polycation, poly-L-lysine, covalently linked to the asialo-orosomucoid glycoprotein (ASOR) (1). ASOR serves as a ligand for recognition by the asialoglycoprotein receptor present in hepatocytes. The subsequent mixture of this conjugate ASORpoly-L-lysine with DNA results in the formation of complexes stabilized by electrostatic interactions, which allows the delivery of single-strand DNA or double-strand DNA specifically to hepatocytes. DNA delivered to the liver in vivo via endocytosis mediated by the asialoglycoprotein receptor is rapidly degraded, presumably in lysosomes, and can be cleared within $48 \mathrm{~h}$ (2). Pharmacological approaches such as the destabilization of microtubules that interfere with the translocation of endosomes to lysosomes have to be developed to overcome the problem of intracellular degradation and to augment the efficiency of directed gene expression.

A recent development was the in vitro assembly of human artificial chromosomes (HACs). Chromosomes are highly structured organelles, formed by a linear DNA molecule wrapped and conjugated to globular hystone proteins. A chromosome has three important parts or components: a centromere (central portion), telomeres (terminal portions), and origins of replication (Figure 1). The functions of telomeres and centromeres are partly known and their structures are being slowly elucidated. The origins of replication are involved in the initial replication of the DNA that forms the chromosome. These three components are sufficient to confer a chromosome function on a DNA fragment. Utilizing molecular biology techniques, it is possible to assemble the three 
essential components to form an artificial chromosome.

Recently, a group of researchers in Cleveland (3) described the assembly of first generation human artificial minichromosomes using new assemblies of $\alpha$-satellite DNA (tandem repeats of DNA sequence present in centromeres), telomeric DNA (tandem repeats of TTAGGG), and other fragments of genomic DNA. The creation of HACs is a major step forward in the studies of the functions of human chromosomes and the expression of large DNA sequences. HACs can be utilized as vectors for very large DNA sequences that in this form can be stably maintained within cells for studies of DNA sequence and gene expression, or the effect of its organization and relative position on the integrity and stability of the artificial chromosome. The cloning of genes into HACs also opens the possibility for the stable introduction and physiological expression of therapeutic genes. However, efficient HAC delivery methods have yet to be developed for the use of HACs in somatic gene therapy protocols.

Gene transfer can also be accomplished by using DNA encapsulated into agents such as cationic lipids or phospholipids, to form cationic liposomes. Liposomes are usually prepared from bipolar phospholipids and consist of a hydrophilic core delimited by an external lipid layer (4). Cationic lipids interact electrostatically with the strongly anionic DNA molecule promoting a complete encapsulation of the nucleic acid. The liposomes produced in this way have a broad spectrum of cellular infectivity. In a 1993 paper, Zhu and coworkers (5) reported that a single intravenous injection of cationic liposomes carrying a plasmid with the chloramphenicol acetyl-transferase (CAT) gene under control of the strong CMV promoter was capable of transducing many different tissues in the mouse.

However, for in vivo use, especially for systemic applications, a series of modifica- tions have yet to be developed both in the surface of liposomes and in the encapsulated DNA. It would be desirable, for instance, to develop modified liposomes capable of escaping the reticuloendothelial system and tissue macrophages (e.g. Kupffer cells). This could be done through the coupling of target-ligands on the liposome surface. These ligands would serve also to direct liposomes to specific targets.

An important barrier for the expression of transgenes that are introduced via liposomes is the transport into the nucleus. The co-encapsulation of viral envelopes with incorporation of nucleophilic proteins that contain nuclear internalization signals (e.g., the high mobility group proteins, HMG1 proteins) can augment the efficiency of nuclear localization and gene transcription (6-8). Modifications of the encapsulated DNA include the utilization of tissue-specific promoter-enhancer elements to achieve a tissue-specific expression. Tissue targeting and localization can also be improved by direct injection of liposomes into the desired region.

\section{Physical methods}

DNA vectors can be introduced into cells via a variety of physical methods (Table 2). Conceptually the most obvious of such methods, direct injection, requires sophisticated techniques for injection on a micro-scale.

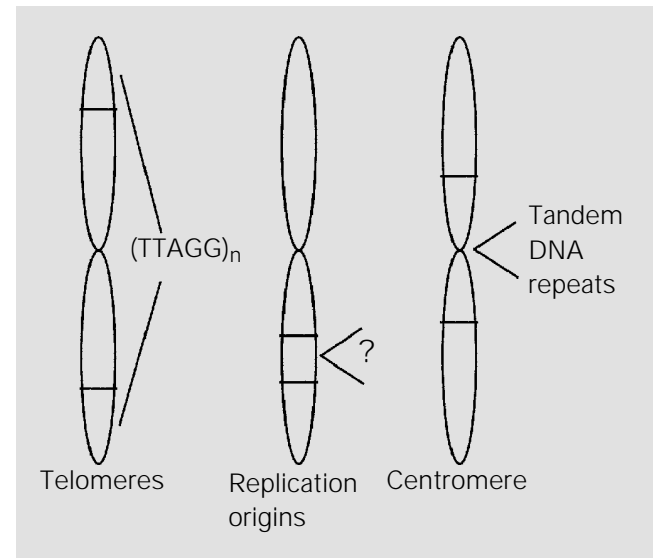

Figure 1 - Basic functional elements in chromosomes. 
This technique, however, is limited by the fact that only a relatively small number of cells can be injected within a given period of time. In spite of the efforts to automate the microinjection techniques, the small number of cells that can be injected each time continues to be a serious limitation. This method of gene transfer could be of interest and clinical utility if a small number of purified bone marrow cells were injected and cell culture conditions were found to expand them substantially. However, the problem of transient expression would still persist, since most of the injected cells would not be capable of sustaining the expression for long periods. This problem requires additional improvements in the vector sequence so as to augment its integration efficiency, for example.

There are other physical methods that can be applied to a larger number of cells. One of such methods is electroporation that can be used to introduce DNA into cells in culture. However, cell viability among receptor cells varies enormously with different cell types. A physical method that has been

Table 2 - Physical methods for introducing genes into mammalian cells.

\begin{tabular}{|c|c|c|}
\hline Method & Advantages & Disadvantages \\
\hline $\begin{array}{l}\text { Direct } \\
\text { microinjection }\end{array}$ & $\begin{array}{l}\text { - high transfection rates } \\
\text { - avoids cytoplasmic and } \\
\text { lysosomal degradation of } \\
\text { the injected material }\end{array}$ & $\begin{array}{l}\text { - good for ex vivo use only } \\
\text { - the technique is labor-intensive } \\
\text { and requires well-isolated cells } \\
\text { - potential for use in germline } \\
\text { gene therapy presents technical } \\
\text { and ethical issues }\end{array}$ \\
\hline Electroporation & - high transfection rate & $\begin{array}{l}\text { - good for ex vivo use only } \\
\text { - excessive cell death renders the } \\
\text { procedure less efficient }\end{array}$ \\
\hline Plasmid injection & $\begin{array}{l}\text { - simplicity } \\
\text { - 2-19 kb can be easily } \\
\text { transferred into the muscle } \\
\text { - good for use in gene } \\
\text { vaccines }\end{array}$ & $\begin{array}{l}\text { - a low percentage of fibers } \\
\text { expresses the transgene after } \\
\text { injection } \\
\text { - use limited to skin, thymus and } \\
\text { striated muscle }\end{array}$ \\
\hline $\begin{array}{l}\text { Ballistic injection } \\
\text { of DNA }\end{array}$ & $\begin{array}{l}\text { - high transfection rates } \\
\text { - delivery of precise dosages } \\
\text { - good for use in gene } \\
\text { vaccines }\end{array}$ & $\begin{array}{l}\text { - transient expression } \\
\text { - considerable cell lesion in the } \\
\text { center of the region reached by } \\
\text { the shot }\end{array}$ \\
\hline
\end{tabular}

originally used in gene transfer to plant cells and tissues (9) and then applied to a variety of organisms including mammal cells and tissues (10-16) consists of coating tiny spheres of a heavy metal (e.g., gold) with DNA, and then shooting these coated particles against the target cells at high speed. The accelerated particles penetrate the cells carrying the DNA. Initial studies performed with this technique have provided encouraging results and created the opportunity for its in vivo application by direct shooting against a selected tissue or organ.

\section{Biological methods: viral vectors}

Viruses are natural gene vectors; they are evolving in connection with virtually all kinds of organisms, from bacteria to plants and animals. The specific biomolecular systems for gene transfer, gene recombination and gene expression adopted by the viruses constitute powerful tools for the construction of more efficient and safe vectors, with precise indications of use. Bacteriophage, baculovirus, retrovirus, adenovirus, herpes simplex virus, vaccinia, human immunodeficiency virus (HIV), polyoma virus and adeno-associated virus are examples of viruses that have been successfully modified by the techniques of recombinant DNA. All of these viruses already have applications in research, agriculture and medicine. Conceptually, it is not surprising that animal viruses have been used as vectors for gene transfer to mammal cells (Table 3). In this article, I shall review in some depth the main properties of three of them: retrovirus, adenovirus and adeno-associated virus.

\section{Retroviral vectors}

A murine retrovirus, the Moloney murine leukemia virus (MoMuLV) was the first vector system to be developed for clinical applications of gene therapy. Utilizing recombinant DNA techniques, the genes of the 
viral genome which are involved in the replication of the MoMuLV - gag, pol and env - are removed and replaced by a gene of interest. What remains from the retrovirus are its regulatory elements: the long terminal repeats (LTR) which function as provirus integration signals and transcription promoters, and a packaging signal, to allow the accommodation of the transcribed RNA into a viral particle. To produce retroviral vectors carrying a gene of interest, it is necessary to use a packaging cell line harboring the gag, pol and env genes which have been previously incorporated into the genome of such cells. The vectors are produced in high titers in the packaging cells, purified and injected into the patient (in vivo gene therapy) or put in contact with cells collected from the patient and maintained in cell culture conditions (ex vivo gene therapy). Retroviral vectors have the ability to enter the target cells, transcribe their RNA into DNA (owing to the activity of viral reverse transcriptase), and integrate stably in a chromosome of the host cell as a result of the presence of the remaining retroviral regulatory sequences. Once integrated, the inserted gene can be expressed to produce the desired therapeutic protein. Viral vectors devoid of the genes involved in viral replication are dubbed "defective" or "crippled" and thus are not able to produce more replication competent virus inside the target cell. The vector acts as a final gene transfer agent, leaving a copy of its gene sequence integrated in the host cell genome.

Advantages of retroviral vectors include the fact that they are well known and well characterized, the possibility to well characterize them and to produce them in high titers $\left[10^{6} \mathrm{PFU} / \mathrm{ml}\right.$ (plaque forming units per $\mathrm{ml}$ ), or higher], and their high transfection efficiency which has been validated in various cell types. Disadvantages include an accommodation limit of 7-8 $\mathrm{kb}$ of DNA, the need that the target cells be in cell division to allow for the integration of the vector (limit- ing the use of retroviral vectors to mitotic cells), and the potential of insertional mutagenesis due to the fact that retroviral vectors integrate at random in the genome. The latter feature has the potential to interrupt important genes in the cell, with serious consequences that include oncogenesis through the activation of proto-oncogenes or inactivation of tumor suppressor genes. Fur-

Table 3 - Biological methods for introducing genes into mammalian cells.

\begin{tabular}{|c|c|c|}
\hline Vector systen & n Advantages & Disadvantages \\
\hline Retrovirus & $\begin{array}{l}\text { - high transduction rates in vitro } \\
\text { - large host spectrum among } \\
\text { dividing cells } \\
\text { - system is well studied } \\
\text { and known } \\
\text { - integration in the host genome } \\
\text { - vector proteins are not } \\
\text { expressed in the host }\end{array}$ & $\begin{array}{l}\text { - immunogenic } \\
\text { - requires dividing cells } \\
\text { - risk of insertional mutagenesis } \\
\text { - risk of reversion to the wild type } \\
\text { - inactivation by complement } \\
\text { fractions in the serum } \\
\text { - relatively low titers } \\
\text { - low delivery rates in vivo }\end{array}$ \\
\hline Adenovirus & $\begin{array}{l}\text { - large host spectrum, including } \\
\text { mitotic as well as post-mitotic } \\
\text { cells } \\
\text { - high titers } \\
\text { - high transduction efficiency } \\
\text { - episomal viral genome } \\
\text { - wild type virus causes a mild } \\
\text { disease } \\
\text { - non-enveloped }\end{array}$ & $\begin{array}{l}\text { - immunogenic } \\
\text { - reversal to wild type } \\
\text { - short period of gene expression } \\
\text { in dividing cells (clearance of } \\
\text { the episome) } \\
\text { - leakage of viral proteins }\end{array}$ \\
\hline $\begin{array}{l}\text { Adeno- } \\
\text { associated } \\
\text { virus (AAV) }\end{array}$ & $\begin{array}{l}\text { - large host spectrum, including } \\
\text { mitotic as well as post-mitotic } \\
\text { cells } \\
\text { - no associated human disease } \\
\text { - preferential site-directed } \\
\text { integration of DNA }\end{array}$ & $\begin{array}{l}\text { - limited DNA packaging capacity } \\
\text { - integration is not always site- } \\
\text { directed } \\
\text { - immunogenic (?) }\end{array}$ \\
\hline $\begin{array}{l}\text { Herpes } \\
\text { simplex } \\
\text { virus (HSV) }\end{array}$ & $\begin{array}{l}\text { - episomal } \\
\text { - may produce latent infection } \\
\text { during whole life span } \\
\text { (especially in the CNS) } \\
\text { - accommodates large inserts } \\
\text { - high titers }\end{array}$ & $\begin{array}{l}\text { - immunogenic } \\
\text { - different viruses have different } \\
\text { selectivity } \\
\text { - EBV is oncogenic } \\
\text { - activation of latent virus } \\
\text { - low transduction efficiency } \\
\text { - transient expression by available } \\
\text { vectors } \\
\text { - system is under development }\end{array}$ \\
\hline HIV & $\begin{array}{l}\text { - infects and transduces mitotic } \\
\text { and post-mitotic cells } \\
\text { - long duration of gene expression }\end{array}$ & $\begin{array}{l}\text { - system is poorly understood } \\
\text { - low efficiency in vivo }\end{array}$ \\
\hline Vaccinia & $\begin{array}{l}\text { - potential for the development } \\
\text { of a variety of gene vaccines }\end{array}$ & $\begin{array}{l}\text { - use is restricted to individuals } \\
\text { not previously vaccinated } \\
\text { - use in the immunocompromised } \\
\text { is not indicated }\end{array}$ \\
\hline
\end{tabular}


ther disadvantages of retroviral vectors that limit their in vivo use include their inactivation by complement in serum, and the poorly understood spontaneous inactivation of the LTR promoter function.

\section{Adenoviral vectors}

Human adenoviruses are non-enveloped DNA-viruses with a linear double-strand DNA of about $36 \mathrm{~kb}$, encapsulated in an icosahedral capsid measuring 70-100 nm in diameter. The capsid has in its vertices rodlike structures that interact with cell receptors (Figure 2). In the wild, adenoviruses are capable to infect cells in the gastrointestinal
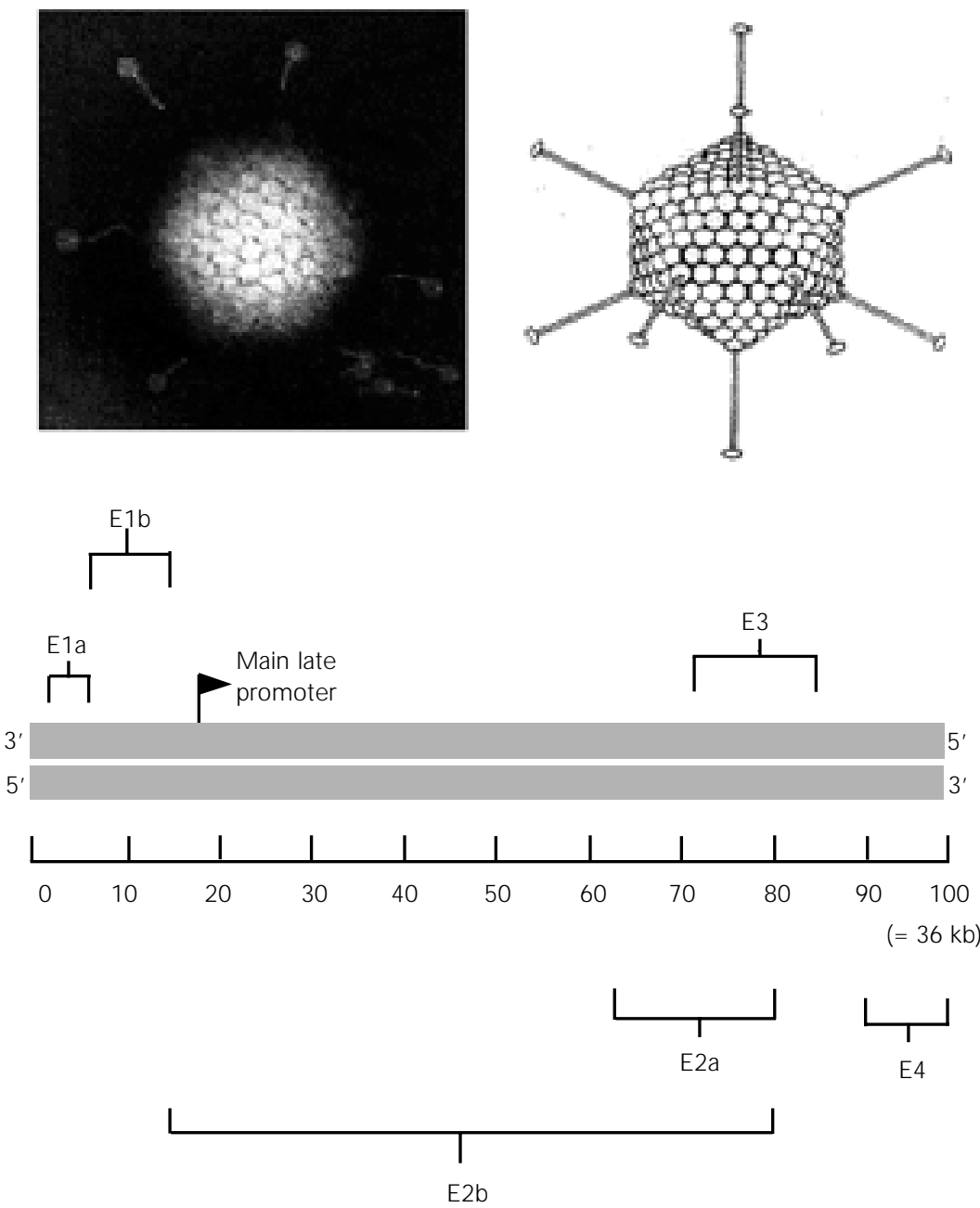

Figure 2 - Adenoviral particles (top); representation of the adenoviral genome, with important genes indicated (bottom). $100=36 \mathrm{~kb}$. See Ref. 31 . tract causing common cold, gastroenteritis in children or epidemic conjunctivitis. The adenoid glands are one of its targets, from which the name adenovirus has originated. Infections involving the urinary tract, hepatic pathways and the central nervous system can occur sporadically. The majority if not the totality of adults has been exposed to adenoviruses and has antibodies.

Differently from retrovirus, adenovirus does not depend on host cell division for its replication, and its chromosome rarely integrates into the cell genome, remaining episomal in most cases. Integration seems to occur only in the presence of high levels of infection in dividing cells, but this event does not contribute significantly to the utility of these viruses as vectors. Adenoviral vectors have a broad spectrum of cell infectivity that includes virtually all post-mitotic and mitotic cells, and also can be produced in high titers.

The genomic structure of adenovirus is more complex than that of retrovirus. The adenoviral genome codes for approximately 15 proteins. Viral gene expression occurs in a coordinated fashion and is mainly directed by the E1A and E1B genes, localized in the 5 portion of the adenoviral genome (Figure 2).

These genes have transactivation functions for the transcription of various viral and host cell genes. Since E1 genes are involved in adenoviral replication, their removal renders the virus replication incompetent or "defective". The removal also creates room for the insertion of a gene of therapeutic interest. An exogenous DNA can also replace the $\mathrm{E} 3$ region, whose product is involved in the ability of the virus to escape the host immune system. Some properties of the adenovirus E1 proteins can be relevant in some forms of gene therapy, namely cancer gene therapy. E1A is the first viral transcription unit to be expressed after the viral chromosome has reached the nucleus. A constitutively active promoter with duplicated enhancer elements controls transcription of the 
E1A unit. E1A transcripts also are capable to induce apoptosis through the induction of the $p 53$ gene. An E1A protein appears to stabilize the p53 protein, resulting in the accumulation of this protein in the nucleus, and high levels of the p53 protein can block the progression of the cell cycle and induce apoptosis. Similarly to the E1A protein, a $55-\mathrm{kDa}$ E1B protein of type 5 adenovirus also modulates the progression into the cell cycle. This E1B protein has the p53 protein as a ligation target, and has the ability to block E1A-induced apoptosis.

Packaging cells carrying adenoviral genes that provide transcomplementation functions are also required to produce defective adenoviral vectors. Packaging cells of the NIH293 cell lineage are human embryo kidney (HEK) cells that have been previously transformed with type 5 adenovirus. These cells retain the E1A and E1B regions of the viral genome covalently linked to their genomic DNA. The construction of an adenoviral vector begins with the production of a bacterial plasmid carrying the adenovirus genome deleted in the $\mathrm{E} 1$ and $\mathrm{E} 3$ regions. E1 deletion renders the virus defective, whereas E3 deletion does not affect viral replication. The genes of interest can be cloned in these deleted regions, and the plasmid can be growth-amplified in a bacterial cell culture. The purified plasmid is then transfected to 293 cells, where it is packaged into defective adenoviral particles. The virions are isolated from the cell culture medium and purified by ultracentrifugation in cesium chloride gradients to achieve suspensions with high viral titers (higher than $10^{13} \mathrm{PFU} / \mathrm{ml}$ ). The purified viral vector is stable in a variety of aqueous buffers, and can be frozen for long periods without loss of activity.

An alternative strategy for the production of adenoviral vectors begins with the preparation of a plasmid in which the gene of interest is flanked by adenoviral DNA sequences. These sequences serve as control regions and contain packaging signals and sites for recombination with the genomic adenoviral DNA that will be used to reconstitute defective adenovirions inside the packaging cell. The cotransfection of this plasmid together with the adenoviral genomic DNA with selected deletions, e.g., E1 and E3, to 293 cells leads to the formation of adenoviral particles, through homologous recombination, with the gene of interest replacing the E1 and E3 genes. Thus, both direct cloning and homologous recombination can be used to produce a defective adenovirus. Further development of new packaging cell lines carrying a larger number of adenoviral genes for transcomplementation, or helper adenovirus, shall enable the production of adenoviral vectors containing a small number of adenoviral sequences, and a great deal of heterologous sequences. An "all deleted" adenoviral vector has been recently produced (17). This vector carries the full-length human dystrophin cDNA.

The disadvantages of adenoviral vectors include: i) short duration of transgene expression since the vector usually does not integrate stably into the host cell genome; ii) limits to the size of the DNA sequence of interest to be packaged into the adenoviral particle, and iii) humoral and cellular immune responses triggered against the adenoviral particles or against the host cell that eventually expresses adenoviral proteins, in addition to the transgene expression. The latter is called "viral protein leakage". Further problems include the potential of viral replication through transcomplementation of the vector by cell proteins with functions homologous to the E1A protein, or through a superinfection with wild adenovirus. Actually, this concerns not only adenoviral vectors, but also any kind of defective viral vector.

\section{Adeno-associated vectors}

The unfavorable properties of adenoviral and retroviral vectors discussed above in- 
Figure 3 - Adenovirus (Ad) and adeno-associated virus (AAV), AAV genome, different transcripts. ITR, Inverted terminal repeats. See Ref. 32. clude the lack of integration of adenoviral DNA and the random integration of retroviral vectors into the host cell genome. Besides, these vectors can trigger immune responses of the humoral and cell types, and they can be pathogenic.

Vectors alternatively indicated to circumvent these problems are based on the adenoassociated virus (AAV), a small non-enveloped, non-pathogenic DNA virus belonging to the Parvoviridae family. The AAV genome is a single-strand DNA molecule, 4681 bases long including two inverted terminal repeats (ITRs). ITRs are 145 bases long palyndromic sequences involved in the regulation of the AAV cell cycle. They are located in the 5 ' and 3 ' terminal portions of the viral genome, and serve as origins and initiators for DNA replication. Flanked by the ITRs, two large open reading frames code
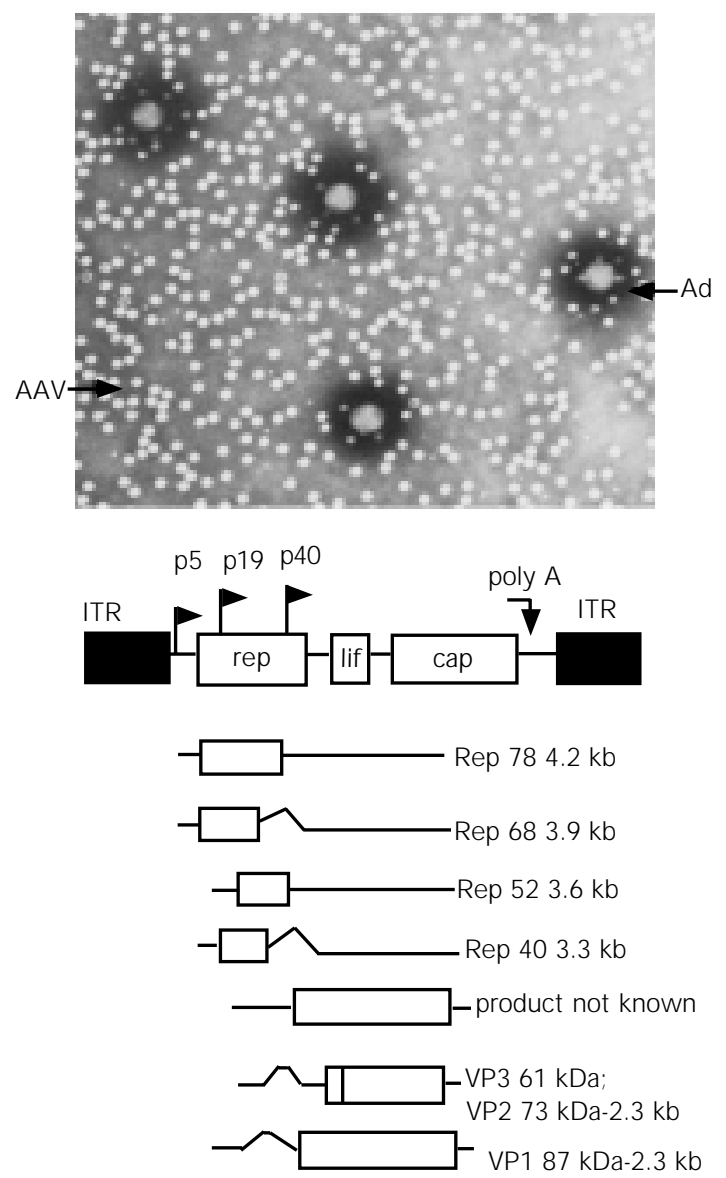

for a regulatory protein and a structural protein, rep and cap, respectively (Figure 3). The reading region located in the 5 ' region (rep gene) encodes four non-structural proteins involved in the genomic replication. The 3' portion contains the cap gene, which encodes three structural proteins for the formation of the viral capsid.

AAV is considered to be a dependovirus because it is capable of replication in a cell only in the presence of a helper virus (adenovirus or herpes virus), which provides by transcomplementation the helper factors that are essential for its replication. In the absence of a helper virus, the AAV genome preferentially integrates into a specific site on the short arm of chromosome 19, between q13.3 and qter, called AAVS1. The ITRs as well as a rep transcript (18) play an important role in this process, resulting in a latent infection in mitotic as well as in postmitotic cells. Recently, episomal forms of the virus have been identified, and the integration into non-specific sites has been documented; however, there is no report of insertional oncogenesis. The latent provirus can be rescued and replicated following a superinfection with the helper virus.

There is a great interest in using AAV as a potential gene vector in human gene therapy trials (19). Among its most favorable properties are i) no relation to human diseases; ii) broad infectivity spectrum, and iii) ability to stably integrate into the host genome. This kind of integration can occur in cells that are not dividing, although at a lower frequency than in dividing cells. The site-directed integration is also a most favorable property of AAV.

Recombinant adeno-associated viral vectors (rAAV) are derived from plasmids that carry ITRs flanking the exogenous gene of interest. These vectors can be packaged into the AAV capsid through co-transfection with the following elements in packaging cells: i) adenovirus and ii) a second packaging plasmid carrying the rep and cap genes. The 
rAAV is rescued from cell lysates, and the helper virus is removed or inactivated (Figure 4).

The disadvantages of rAAV particles as gene vectors include their small genome size (5 $\mathrm{kb}$ is the upper limit to AAV encapsidation), and the difficulty to produce large amounts of the vector. However, several improvements have been obtained in the production and use of AAV-based vectors. Richard J. Samulski and coworkers (20) have constructed a plasmid, pSub201, which contains the full-length AAV genome. Since then, the difficulty to produce rAAV DNA on a large scale has been minimized by the utilization of recombinant plasmids that can be growth-amplified in bacterial cultures. The size limit has been circumvented in the sense that the rAAV DNA can be introduced into cells by lipofection. A summary of the advantages and disadvantages of the main viral vectors is provided in Table 3 .

\section{Combination of viral and non-viral elements}

The combination of viral and non-viral elements can be used to increase the efficiency of gene transfer to cells. The incorporation of adenoviral lysosomal degradation escape functions to encapsulated DNA is an example of such strategy $(21,22)$. Complexes are prepared with adenoviral particles and poly-L-lysine linked to DNA, or to DNA encapsulated into liposomes. These complexes enable the simultaneous delivery of its components to each lysosome in the cell, diminishing lysosomal degradation of the DNA, and increasing the efficiency of transfection. Since adenoviruses used in this strategy can be irradiated to become non-infectious, the method has the potential to eliminate completely the use of any infectious viral DNA. However, there are unresolved questions concerning the duration of gene expression using such complexes, in vivo efficiency, etc.
Another example of combination of viral and non-viral elements was mentioned in the AAV section and consists of the construction of plasmids carrying the AAV ITR sequences flanking the gene of interest to promote the transformation of cells. AAV can be replaced for this kind of construction encapsulated into liposomes. The level of gene expression and transgene retention is similar to that observed with AAV alone. In 1994, Philip and coworkers (23) reported that the presence of the ITRs of AAV in plasmids could confer prolonged persistence of the transfected DNA if compared to the transfection mediated by conventional plasmids lacking ITRs. In 1995, Vieweg and colleagues (24) demonstrated that the utilization of plasmids containing the ITR sequences of AAV, complexed to cationic liposomes can produce gene transfer and in vitro interleukin-2 (IL-2) gene expression that are 3 to 10 times higher than the levels obtained with plasmids lacking the ITRs. The levels of IL-2 expression achieved with these plasmids in an in vivo model of antitumor induction were comparable to the secretion levels obtained with the use of retroviral vectors. Expression levels are possibly dose-dependent, according to results

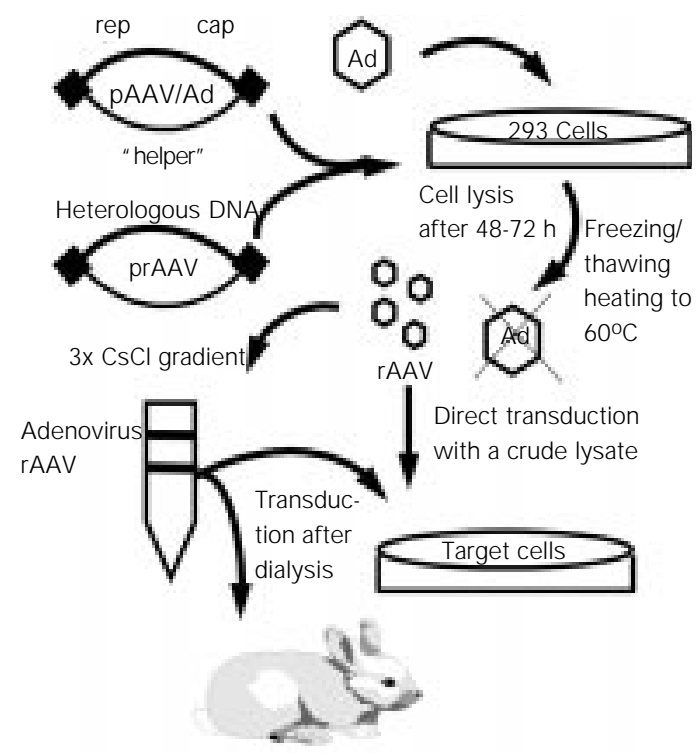

Figure 4 - Steps in the production of recombinant adeno-associated particles (rAAV). Ad, Adenovirus. From reference 33 , with modifications. 
reported by Malik and coworkers (25) showing that the frequency of AAV integration can jump from 2 to $49 \%$ of transfected cells, only by changing the AAV titer from 1.3 multiplicity of infection (MOI) to $130 \mathrm{MOI}$, respectively, representing a 25 -fold increase in integration efficiency. This suggests that a higher number of rAAV genomic particles increases the likelihood of a copy being integrated into the specific chromosomal site.

A further improvement involves changing the structure of the encapsulating liposome. Hong and coworkers (26) combined adenoviral capsid proteins or adenoviral fiber proteins with liposomes, obtaining a considerable increase in the efficiency of transfection of the reporter gene $L a c Z$ cloned in an AAV-derived vector. Taken together, these results allow us to reach the following conclusions: i) plasmids carrying ITR sequences produce high and stable levels of expression, and ii) cationic liposomes are an excellent alternative to carry rAAV into cells without triggering any immune response by the host.

\section{The potential use of mitochondria as DNA vectors}

Mitochondria are the only cytoplasmic organelles that possess their own DNA (mtDNA). In this respect, mitochondria look

Figure 5 - Potential use of mitochondria as gene vectors for stable gene transfer to the cytoplasm, as compared to liposomes and adenoviral vectors. This figure shows what happens to liposomes (lysosomal degradation or nuclear incorporation as an episome) and adenovirus (episomal incorporation) used in gene transfer. Mitochondria apparently possess membrane properties that endow them with cytoplasm stability.

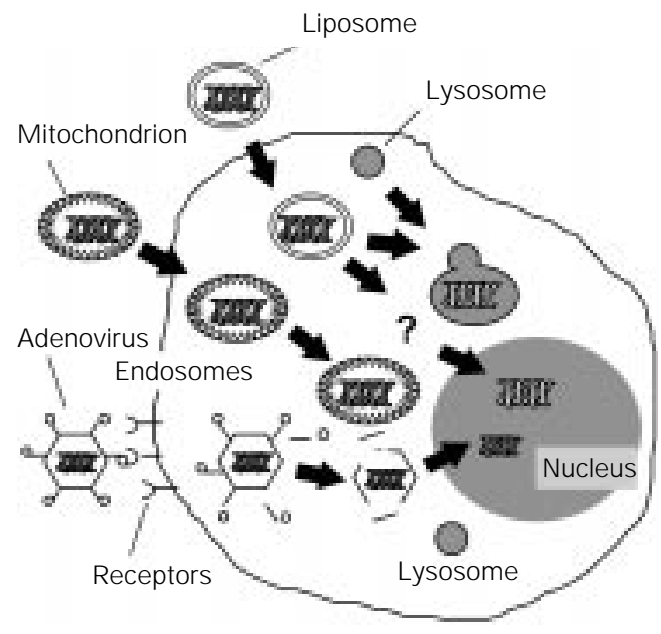

like liposomes that are used in gene transfer, constituted by lipid membranes enveloping DNA molecules (Figure 5). Since mitochondria can be purified by ultracentrifugation from cell homogenates, they could be used as gene transfer vectors. Mitochondria isolated from donor blood can be fused to receptor cells, generating viable cytoplasmic hybrids (cybrids) $(27,28)$.

The use of mitochondria as gene vectors has potential application in the replacement of mitocondrial DNA (mtDNA) in cells with oxidative phosphorylation defects caused by mutations of the mtDNA. mtDNA mutations are linked to a series of maternally inherited degenerative neuromuscular syndromes including mitochondrial encephalopathy, lactic acidosis, vomiting and stroke (MELAS), myoclonic epilepsy and ragged-red fiber (MERRF), neurogenic muscular weakness, and ataxia and retinitis pigmentosa (NARP), among others. mtDNA mutations also occur in cells of the somatic lineage and accumulate with aging and in conditions of oxidative stress $(29,30)$, and may account for a great deal of the phenotypes of advanced age, including muscle weakness, Alzheimer disease, and Parkinson disease.

Technically, the in vivo use of mitochondria as gene vectors is cumbersome. Targeting the mtDNA to mitochondria in vivo offers a more viable approach to somatic gene therapy of diseases of the mitochondrial genome.

\section{In search of the ideal vector: the future of gene therapy}

Ideally, a vector should accommodate an unlimited amount of inserted DNA, lack the ability of autonomous replication of its own DNA, be easily manufactured, and be available in concentrated form. Secondly, it should have the ability to target specific cell types or to limit its gene expression to specific cell types, and to achieve sustained gene expression in the long term or in a 
controlled fashion. Finally, it should not be toxic or immunogenic. Table 4 shows a comparison of seven main vector systems available to date. The analysis of the properties of the main vector types reviewed in Tables 1-3 shows that none of these vector systems conforms to the notion of the "ideal vector" (Table 5).

There still exist serious limitations regarding the efficiency and cell specificity of the available gene vector systems. Recombinant viral vectors are the most potent gene transfer vectors, but host immune response, safety issues, and the difficulty of scaling up their production constitute important barriers for their clinical use. The delivery of DNA via liposomes or via cell receptor targeting offers alternatives for virus-mediated gene transfer, but the levels of gene expression obtained with these methods need to be significantly improved before they can be used for the treatment of human diseases. Furthermore, our knowledge about the transcriptional control is incomplete. All these aspects are under intense investigation; methods for ex vivo and in vivo gene transfer are under rapid development, and there is the hope that considerable progress will be attained within the next decade.

The development of highly efficient systems for viral packaging and the refinement of the purification and concentration processes could improve the titers of viral vectors to values that would allow gene transfer through systemic administration. Targeted delivery could be made possible through the incorporation of single chain antibodies raised against cell surface antigens or ligands for transmembrane receptors incorporated into the retrovirus envelope or adenovirus penton proteins, and there are encouraging signs that this strategy could reach success.

"Design vectors" are expected to be available in the short term. These vectors shall incorporate the most useful elements of presently available viral and synthetic systems, with variations depending on the applica- tion. For example, the ITR of AAV, that promote stable chromosomal integration, can be combined to sequences of other vectors with more insert accommodation capacity. Integration efficiency can be increased through the packaging of a functional recombinase together with the gene expression construction in the form of liposome complexes directed at a specific cell type by antibodies or receptor-ligand proteins.

In the long term, new delivery methods could be developed for the intranuclear transfer of HACs carrying whole gene blocks

Table 4 - Vector comparison.

HSV, Herpes simplex virus; AAV, adeno-associated virus.

\begin{tabular}{|c|c|c|c|c|c|c|c|}
\hline & Retrovirus & Adenovirus & HSV & AAV & Liposomes & $\begin{array}{c}\text { DNA } \\
\text { injection } \\
\text { (plasmid) }\end{array}$ & $\begin{array}{c}\text { Bio- } \\
\text { ballistics } \\
\text { (gene gun) }\end{array}$ \\
\hline Insert size & $8 \mathrm{~kb}$ & $8 \mathrm{~kb}-28 \mathrm{~kb}$ & $>20 \mathrm{~kb}$ & $<4 \mathrm{~kb}$ & $>20 \mathrm{~kb}$ & $>20 \mathrm{~kb}$ & $>20 \mathrm{~kb}$ \\
\hline Title & $10^{7}-10^{10}$ & $10^{11}$ or + & $10^{8}$ & $10^{9}$ & - & - & - \\
\hline Integration & Yes & No & No & Yes & No & No & No \\
\hline $\begin{array}{l}\text { Duration of } \\
\text { trangene } \\
\text { expression }\end{array}$ & Variable & Transient & Transient & Variable & Transient & $\begin{array}{l}\text { Only in } \\
\text { muscle }\end{array}$ & Transient \\
\hline $\begin{array}{l}\text { Delivery } \\
\text { rates } \\
\text { in vivo }\end{array}$ & Low & High & High & High & Variable & Low & $\begin{array}{c}\text { Requires } \\
\text { exposed } \\
\text { tissue }\end{array}$ \\
\hline $\begin{array}{l}\text { Transfects } \\
\text { quiescent } \\
\text { cell }\end{array}$ & No & Yes & Yes & Yes & Yes & Yes & Yes \\
\hline
\end{tabular}

Table 5 - The ideal vector for gene transfer in gene therapy protocols.

\begin{tabular}{ll}
\hline Insert size & - can accommodate one or more genes \\
Targeting & - delivery to specific cell types or gene expression limited \\
& to target cells \\
Regulation & - transgene expression levels can be up- or \\
& down-regulated \\
Safety and stability & - safe for the patient and the environment \\
& - devoid of the risk of insertional mutagenesis \\
Immune response & - none \\
Titles & - high concentrations, final product stable \\
Manufacture & - easy, reproducible, scale-up and standardization possible
\end{tabular}


with natural control elements. In the future, basic research shall try to define which genomic elements are involved in the temporal and spatial control of gene expression during the whole lifespan of an organism. Advances in these fields will require parallel developments in vector design before the knowledge can be utilized in clinical practice.

From the wide variety and creativity of vector systems and methods of gene transfer under development it seems clear that in the future there will be a wide choice of different gene transfer methods for different clinical applications. This situation certainly will broaden the opportunities for the use of gene transfer technology in the clinical context. Gene therapy promises to be a fruitful area of scientific and clinical research for many years to come, and there is no doubt that it will become an important clinical practice in the next century.

\section{References}

1. Findeis MA, Wu CH \& Wu GY (1994). Ligand-based carrier systems for delivery of DNA to hepatocytes. Methods in Enzymology, 247: 341-351.

2. Stankovics J, Crane AM, Andrews E, Wu CH, Wu GY \& Ledley FD (1994). Overexpression of human methylmalonyl CoA mutase in mice after in vivo gene transfer with asialoglycoprotein/polylysine/DNA complexes. Human Gene Therapy, 5: 1095-1104.

3. Harrington J J , Van Bokkelen G, Mays RW, Gustashaw K \& Willard HF (1997). Formation of de novo centromeres and construction of first-generation human artificial microchromosomes. Nature Genetics, 15: 345-355.

4. Lasic DD \& Papahadjopoulos D (1995). Liposomes revisited. Science, 267: 12751276.

5. Zhu N, Liggitt D, Liu Y \& Debs R (1993). Systemic gene expression after intravenous DNA delivery into adult mice. Science, 261: 209-211.

6. Hangai $\mathrm{M}$, Kaneda $\mathrm{Y}$, Tanihara $\mathrm{H} \&$ Honda $Y$ (1996). In vivo gene transfer into the retina mediated by a novel liposome system. Investigative Ophthalmology and Visual Science, 37: 2678-2685.

7. Kato K, Nakanishi M, Kaneda Y, Uchida T \& Okada K (1991). Expression of hepatitis $B$ virus surface antigen in adult rat liver: co-introduction of DNA and nuclear protein by a simplified liposome method. J ournal of Biological Chemistry, 266: 3361-3364.

8. Takeda S, Miyoshi S, Omori K, Utsumi T, Kogaki S, Sawa Y, Yanagisawa M \& Matsuda H (1998). Pulmonary disease models induced by in vivo hemagglutinating virus of J apan liposome-mediated endothelin-1 gene transfer. J oumal of Car- diovascular Pharmacology, 31 (Suppl 1): S336-S338.

9. Sanford J C, Klein TM, Wolf ED \& Allen N (1987). Delivery of substances into cell tissues using a particle bombardment process. Particulate Science and Technology, 5: 27-37.

10. Klein TM, Arentzen R, Lewis PA \& Fitzpatrick-McElligott S (1992). Transformation of microbes, plants and animals by particle bombardment. Bio/Technology, 10: 286-291.

11. Klein TM \& Fitzpatrick-McElligott SF (1993). Particle bombardment: a universal approach for gene transfer to cells and tissues. Current Opinion in Biotechnology, 4: 583-590.

12. Sanford J C, Smith FD \& Russell J A (1993). Optimizing the biolistic process for different biological applications. Methods in Enzymology, 217: 483-510.

13. Vainstein $M H$, Alves $S A$, Lima $B D$, Aragão FJ L \& Rech EL (1994). Stable DNA transfection in a flagellate trypanosomatid by microparticle bombardment. Nucleic Acids Research, 22: 3263-3264.

14. Aragão FJ L, Barros LMG, Brasileiro $A C M$, Ribeiro SG, Smith FD, Sanford J C, Faria JC \& Rech EL (1996). Inheritance of foreign genes in transgenic bean (Phaseolus vulgaris L.) co-transformed via particle bombardment. Theoretical and Applied Genetics, 93: 142-150.

15. Tang D, De Vit M \& J ohnston SA (1992). Genetic immunization is a simple method for eliciting an immune response. Nature, 356: 152-154.

16. Rech EL, De Bem R \& Aragão FJ L (1996). Biolistic-mediated gene expression in guinea pigs and cattle tissues in vivo. Brazilian J ournal of Medical and Biological Research, 29: 1265-1267.
17. Haecker SE, Stedman HH, Balice-Gordon RJ , Smith DB, Greelish J P, Mitchell MA, Wells A, Sweeney $\mathrm{HL} \&$ Wilson JM (1996). In vivo expression of full-length human dystrophin from adenoviral vectors deleted of all viral genes. Human Gene Therapy, 7: 1907-1914.

18. Balague C, Kalla M \& Zhang WW (1997). Adeno-associated virus Rep78 protein and terminal repeats enhance integration of DNA sequences into the cellular genome. J ournal of Virology, 71: 3299-3306.

19. Page KW \& Lebkowski J S (1997). Adenoassociated virus: a vector for high-efficiency gene transduction. In: Bertino J R (Editor), Encyclopedia of Cancer. Vol. II. Academic Press, San Diego, CA, 1-9.

20. Samulski RJ , Chang LS \& Shenk T (1987). A recombinant plasmid from which an infectious adeno-associated virus genome can be excised in vitro and its use to study viral replication. J ournal of Virology, 61: 3096-3101.

21. Curiel DT (1994). High-efficiency gene transfer employing adenovirus-polylysineDNA complexes. Natural Immunity, 13: 141-164.

22. Fasbender A, Zabner J, Chillon $M$, Moninger TO, Puga AP, Davidson BL \& Welsh MJ (1997). Complexes of adenovirus with polycationic polymers and cationic lipids increase the efficiency of gene transfer in vitro and in vivo. J ournal of Biological Chemistry, 272: 6479-6489.

23. Philip R, Brunette $E$, Kilinski L, Murugesh D, McNally MA, Ucar K, Rosenblatt J, Okarma TB \& Lebkowski J S (1994). Efficient and sustained gene expression in primary $\mathrm{T}$ lymphocytes and primary and cultured tumor cells mediated by adenoassociated virus plasmids DNA complexed to cationic liposomes. Molecular 
and Cellular Biology, 14: 2411-2418.

24. Vieweg J, Boczkowski D, Roberson KM, Edwards DW, Philip M, Philip R, Rudoll T, Smith C, Robertson C \& Gilboa E (1995). Efficient gene transfer with adeno-associated virus-based plasmids complexed to cationic liposomes for gene therapy of human prostate cancer. Cancer Research, 55: 2366-2372.

25. Malik P, McQuiston SA, Yu X-J, Pepper KA, Krall WJ , Podsakoff GM, Kurtzman GJ \& Kohn DB (1997). Recombinant adenoassociated virus mediates a high level of gene transfer but less efficient integration in the K562 human hematopoietic cell line. J oumal of Virology, 71: 17761783.

26. Hong Z, Guangbin Z, Xiaojun Z, Jian T, Guanghui C, Qianhui $H$, Tongcai $P$ \& Bingquan H (1995). Enhanced adeno-associated virus vector expression by aden- ovirus protein-cationic liposome complex. A novel and high efficient way to introduce foreign DNA into endothelial cells. Chinese Medical J ournal, 108: 332-337.

27. Fukami MH \& Salganicoff L (1973). Isolation and properties of human platelet mitochondria. Blood, 42: 913-918.

28. Chomyn A, Lai ST, Shakeley R, Bresolin N, Scarlato G \& Attardi G (1994). Plateletmediated transformation of mtDNA-less human cells: analysis of phenotypic variability among clones from normal individuals and complementation behavior of the tRNALys mutation causing myoclonic epilepsy and ragged red fibers. American J ournal of Human Genetics, 54: 966-974.

29. Merril CR, Zullo S, Ghanbari H, Herman MM, Kleinman J E, Bigelow LB, Bartko J J \& Sabourin DJ (1996). Possible relationship between conditions associated with chronic hypoxia and brain mitochondrial
DNA deletions. Archives of Biochemistry and Biophysics, 326: 172-177.

30. Wallace DC, Brown MD, Melov S, Graham B \& Lott M (1998). Mitochondrial biology, degenerative diseases and aging. Biofactors, 7: 187-190.

31. Stannard LM (1995). Electron micrograph image of adenovirus. WWW site at: http:// www.uct.ac.za/depts/mmi/stannard/ emimages.html

32. Mayor HD \& Kurstak E (1974). Viruses with separately encapsidated complementary DNA strands. In: Kurstak E \& Maramorosch K (Editors), Viruses, Evolution and Cancer. Academic Press, Inc., New York.

33. Trempe J P (1996). Packaging systems for adeno-associated virus vectors. Current Topics of Microbiology and Immunology, 218: 35-50. 